\title{
Rho-regulatory proteins in breast cancer cell motility and invasion
}

\author{
Min Lin and Kenneth L. van Golen \\ Department of Internal Medicine, The University of Michigan Comprehensive Cancer Center, Ann Arbor, MI, USA
}

Key words: GDP-dissociation inhibitors, GTPase activating proteins, guanine nucleotide exchange factors, metastases, Rho GTPases

\section{Summary}

The importance of the Rho-GTPases in cancer progression, particularly in the area of metastasis, is becoming increasingly evident. This review will provide an overview of the role of the Rho-regulatory proteins in breast cancer metastatis.

\section{Introduction}

The formation and growth of metastases at a distant site is the principal cause of death for most cancer patients, particularly those with breast cancer [1]. Metastases from the breast commonly occur in the sentinal and axillary lymph nodes, the controlateral breast, lungs, spinal cord, brain and bones [2]. Ironically, it has been suggested that less than $0.1 \%$ of neoplastic cells in a primary tumor have the ability to successfully form metastases at distant sites [1]. The inability of the majority of tumor cells to successfully form metastases results from single or multiple phenotypic deficiencies [3-5].

In order for a tumor cell to successfully metastasize it must perform an ordered series of steps that constitute the metastatic cascade. The tumor cell must invade the tissue surrounding the primary tumor, extravasate to the lymphatics or directly to the blood supply, avoid host immune defenses, arrest at the distant site, intravasate and grow [1]. Two key components in obtaining metastatic competence are the acquisition of a motile and invasive phenotype.

\section{A historical perspective of the Rho-GTPases}

Many of the diverse components of the metastatic phenotype are controlled by members of the
Ras-superfamily of small GTP-binding proteins. The Ras-superfamily currently boasts in excess of 130 members, which fall into the Ras, Rho, Arf/Sar1 and Rab/Ran-subfamilies (reviewed in [6]).

All aspects of cellular motility and invasion, including cellular polarity, cytoskeletal organization, and transduction of signals from the outside environment are controlled through an interplay between the Rho-GTPases [7-17]. The Rho-GTPases subfamily consists of small, 20-30 kDa monomeric GTP-binding proteins that are highly conserved throughout evolution in a variety of organisms [18]. Like Ras, Rho proteins are able to bind GDP/GTP and hydrolyze GTP leading to activation of downstream effector molecules subsequently leading to a cellular response [18, 19]. While in their GDP-bound state the GTPases are inactive; conversely when GTP-bound they are active [18-20].

Rho was first isolated in 1985 due to its homology to Ras (Rho stands for Ras homologous) from the sea slug, Aplysia Californica [18]. Identification of three closely related human Rho homologues, RhoA, RhoB and RhoC, soon followed [18]. Other members of the Rho-subfamily were later identified in the early 1990's. Human Cdc42 (a homologue of yeast Cdc42), Rac1 and Rac2 were found to be distinct in function from the other Rho proteins [20-23].

In the time since A. Californica Rho was first described, at least 21 Rho-family genes encoding at 


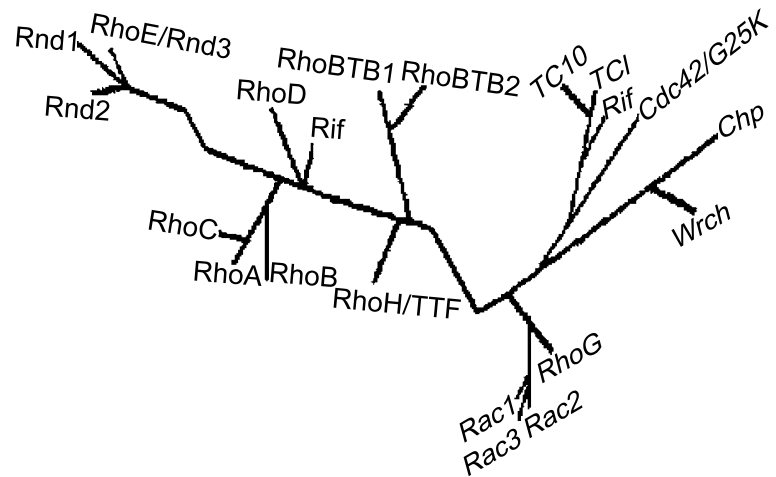

Figure 1. The Rho GTPase subfamily organized by their structure, biochemical features and function. Even though some of these proteins are highly homologous to one another (i.e., RhoA, RhoB and RhoC), they are distinct in their cellular function and consequently the phenotype they produce in cells. This family tree is based on reviews by Wherlock et al. [17] and Ridley [24]

least 23 signaling molecules have been identified in humans [17]. These proteins, although related, are distinct from one another and are organized on the Rho 'family-tree' by virtue of their structural, biochemical and functional features (Figure 1) (reviewed in [17, 24]). Similar to Ras, Rho proteins are localized to the inner plasma membrane by a C-terminal lipid modification. Localization to the plasma membrane is necessary for activation [25]. Interestingly, some Rhofamily members such as Rnd and RhoH appear to lack intrinsic GTPase activity [26-28].

Out of the nearly two dozen Rho genes that have been identified, four members of the Rho-family, RhoA, RhoB, Rac1 and Cdc42, have been studied extensively. A series of elegant experiments were performed early on to determine the functions of the RhoA, Rac1 and Cdc42 proteins. At nearly the same time that RhoA was identified, C3 exotransferase, a toxin derived from Clostridium botulinum was found to effectively target Rho (A, B and C) proteins (and later found to have little or no effect on Rac1 or Cdc42) [29-32]. C3 exotransferase inhibits Rho protein activity by promoting ADP-ribosylation of asparagine 41 and thereby inhibiting the interaction between GTPbound Rho and downstream effector molecules [30]. Although the active state of Rho is unaffected, the GTPase is rendered ineffectual. Using a combination of C3 exotransferase treatment and transfection of cells with constituatively-active forms of RhoA, the Hall and Ridley groups demonstrated the role of Rho in organizing the actin cytoskeleton, specifically forming bundles of actin stress fibers [19, 33]. Other experiments utilizing dominant-negative forms of Rac1 and
Cdc42 established those proteins role in forming actinrich lamellipodia and filopodia, respectively [20-22]. Thus, the individual role of each of these GTPases in cellular motility was established. Rac1 forms the leading lamellipodial edge of the cell. Cdc42 forms the 'ruffles' or 'microspikes' known as filopodia, which redistribute the cell membrane to lamellipodium extension as the cell migrates. And RhoA redistributes the actin stress fibers contracting the cell body in the direction of cell movement. Additional roles of Rho proteins have been demonstrated including control of vesicular trafficking, apoptosis, cellular transformation, cell adhesion, angiogenesis and growth control apoptosis [34-42].

A great deal of excitement ensued over the discovery of Rho-GTPases, as many investigators assumed that due to their homology to Ras, the Rho proteins would also be oncogenes in human cancer. The three isoforms of Ras, Ha-Ras, Ki-Ras and N-Ras, were identified early in the 1980's as oncogenes mutated in a variety of human cancers [43-48].

Approximately, $30 \%$ of human tumors carry an identifiable Ras mutation, which render the GTPase incapable of hydrolyzing bound GTP, thus remaining constitutively active [49]. Breast cancer is the exception, where approximately $5 \%$ of tumors harbor an activating Ras mutation [50]. However, in contrast to Ras, no mutation in any of the Rho proteins has been identified in human tumors. Rather, overexpression of Rho proteins, particularly RhoA and RhoC, appears to be the rule in human cancers $[8,10,51-57]$.

\section{RhoA and RhoC GTPase overexpression in breast cancer}

Initial experiments demonstrated that activated $A$. Californica Rho and RhoA GTPase could act as a dominant oncogene and induce cellular transformation [33, 58, 59]. RhoB GTPase was also shown to play a role in Ras-induced transformation [60]. This promoted several investigators to search several types of human cancers for RhoA mutations. Moscow et al. surveyed breast, ovarian, renal, lung and colon carcinomas specimens for RhoA gene mutations and performed chromosomal analysis on $3 \mathrm{p} 21$, the location of the RhoA gene and an area known to be deleted in several of these cancers [52]. No mutations in RhoA were found, nor was there a correlation between RhoA mRNA expression and the presence or absence of 3p21 deletions. This finding has recently 
been validated by Rihet et al. who compared 14 invasive breast carcinomas with corresponding lymph node metastases [61]. Using RT-PCR followed by denaturing gradient gel electrophoresis (DGGE) to detect the presence of heteroduplexes, the group did not find any RhoA mutations in the patient samples.

Fritz et al. compared tissue from breast, lung and colon with corresponding normal tissue originating from the same patient for RhoA, Rac1 and Cdc42 expression [51]. RhoA protein levels were significantly increased in the all three tumor types as compared with the corresponding normal tissue. Of particular note, protein levels of RhoA, Rac1 and Cdc42 were barely detectable in normal mammary tissue, but were highly expressed in all of the breast tumors tested. Interestingly, they found that RhoA protein levels correlated with increasing breast tumor grade. These findings suggest that overexpression of Rho GTPases, particularly overexpression of RhoA, is a frequent and early event in human cancers.

The role of Rho proteins in breast cancer metastasis has recently been explored. A panel of MTLn3 rat mammary carcinoma cell lines expressing dominant negative mutants of RhoA, Rac1, or Cdc42 was implanted into nude mice [62]. Individually, each dominant negative Rho protein reduced intravasation into the bloodstream and subsequent metastasis [62]. Similarly, it was found that the Ras-Erk and RhoARho kinase (ROCK) pathways cooperate in uorkinasetype plasminogen activator stimulated MCF7 breast cancer cell migration [63]. Both of these studies suggest that the Rho-ROCK, Rac1 and Cdc42 pathways are required for breast cell migration and metastasis.

Inflammatory breast cancer (IBC) is a phenotypically distinct form of locally breast cancer that is highly invasive to the dermal lymphatics and as a consequence is highly metastatic [2, 64-67]. In an attempt to identify genes involved in the unique IBC phenotype, Merajver's laboratory identified RhoC GTPase as being overexpressed in the SUM149 IBC cell line using differential display [54]. In a blinded comparison of IBC samples with stage-matched, non-IBC breast tumor specimens, RhoC was found to be overexpressed in more than $90 \%$ of IBC tumors compared with $38 \%$ of the non-IBC samples [54]. Subsequently, RhoC overexpression has been found to be a potential prognostic marker for small breast tumors $(\leq 1 \mathrm{~cm})$ with a propensity to metastasize [68]. Similar to RhoA, the mechanism of RhoC overexpression in breast cancer is unknown. Southern blot analysis comparing normal human mammary epithelial (HME) cells and the SUM102 breast cancer cell line (which does not overexpress RhoC) with the SUM149 and SUM190 IBC cell lines, did not reveal abnormal gene amplifications or rearrangements (van Golen and Merajver, unpublished observations).

Forced expression of wild-type RhoC in immortalized HME cells nearly recapitulates the IBC phenotype [53, 69]. RhoC overexpressing HME cells grow in soft agar, produce active angiogenic factors, are highly motile, invasive and form orthotopic tumors and micrometastases in nude mice. Treatment of the HME-RhoC cells with C3 exotransferase inhibits the RhoC induced phenotype [14]. Through the use of pharmacologic inhibitors on the SUM149 IBC and HME-RhoC cells, it was determined that RhoC GTPase signals through the phosphoinositide-3-kinase (PI3-K) and mitogen activated protein kinase (MAPK) pathways [14]. Specifically, the ability to grow under anchorage-independent conditions signals through the PI3-K pathway, while motility and invasion signal through the Erk, JNK/SAPK, and p38 arms of the MAPK pathway, and the production of angiogenic factors signals through $\mathrm{p} 38$. As yet, the specific downstream Rho-effector molecules involved in RhoC signaling are unknown. Although Rho-kinase (ROCK) has been suggested to be a downstream target for both RhoA and RhoC, treatment of the cells with the pharmacologic ROCK inhibitor, Y-27632, does not affect the RhoC-induced phenotype (van Golen and Merajver, unpublished observations).

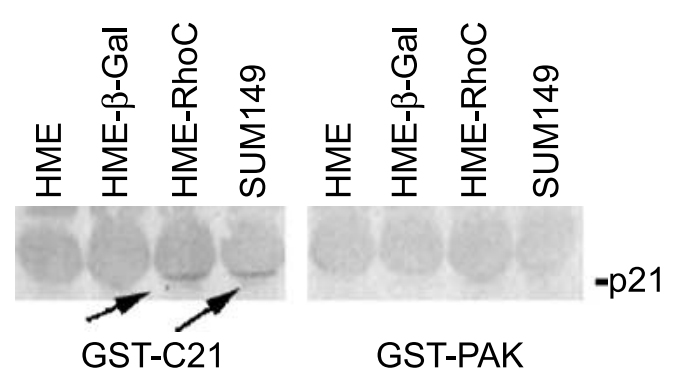

Figure 2. Example of a RhoC GTPase activation assay. GST-fusion proteins of either the C21 Rhotekin Rho-binding domain or the PAK CRIB domain are combine with cell lysates of untransfected HME, $\beta$-galactosidase control transfected HME, RhoC transfected HME and SUM149 IBC cells. The RhoC GST-fusion protein complex is separated by SDS-PAGE, transferred to nitrocellulose and probed with an anti-RhoC antibody. Active, GTP-bound RhoC was detected in HME-RhoC and SUM149 cells in the GST-C21 pulldowns. No active RhoC was detected in the GST-PAK pulldown assay because the CRIB domain is specific for Rac1 and Cdc42. Dr John Collard of the Netherlands Cancer Institute provided the reagents and protocol for this assay. 
Another critical question that our laboratory is beginning to address is the mechanism of RhoC GTPase activation. Using a Rho-activation assay originated and supplied by Dr John Collard [9, 70], and a RhoC specific antibody generated in Merajver's lab [68], we have demonstrated that overexpressed, wild-type RhoC is GTP-bound and active in the SUM149 and HME-RhoC cell lines (Figure 2) [71]. We believe that dysregulation of the Rho-regulatory proteins involved in the normal control of the GTPase cycle leads to aberrant RhoC activation in the absence of mutation.

\section{The GTPase cycle-A brief overview}

Regulation of Ras and Rho GTPase activity is achieved through the interactions of GTPase-activating proteins (GAPs), GDP-dissociation inhibitors (GDIs), GDI dissociation factors (GDFs), and guanine nucleotide exchange factors (GEFs) (Figure 3) [7, 72-74]. In order for Ras and Rho to enter into the GTPase cycle, they must be localized to the inner cell membrane via prenylation [73]. The entire cycle is balanced by GDIs, which prevent GDP dissociation (leading to GTP association) by binding to the prenylation group of the GTPase and sequestering it in the cytoplasm [75-78]. The GDP-bound GTPase is subsequently liberated from the GDI by GDFs and localized to the

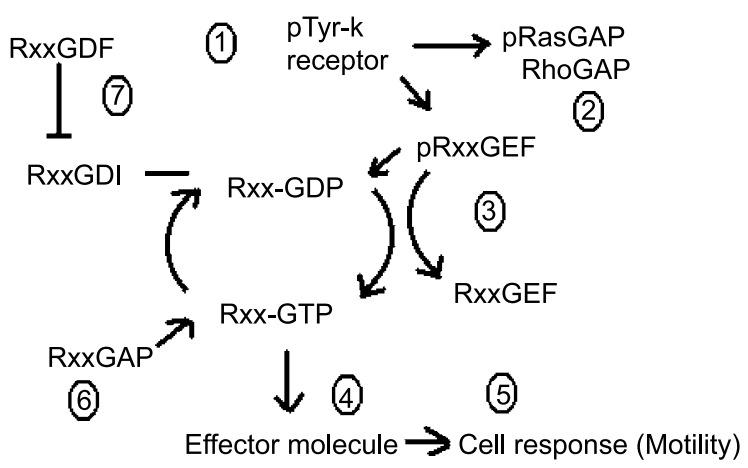

Figure 3. Overview of the GTPase cycle. Rxx-GTPase = Rho-GTPase, Rac-GTPase or Ras-GTPase. (1) Stimulation of a protein tyrosine kinase receptor stimulates (2) phosphorylation, possible dimerization and transient inactivation of GAPs and (3) activation of the GEFs. The GEFs catalyze the exchange of GDP for GTP, activating the GTPase. (4) The active GTPase interacts with downstream effector molecules resulting in (5) a cellular response, in this example motility. (6) The GAP proteins catalyze the hydrolysis of GTP to GDP leading to inactivation of the GTPase. (7) The entire cycle is balanced by the GDIs, which binds to the prenylation group of the GTPase keeping it sequestered and inactive in the cytoplasm until released by GDFs. inner plasma membrane [75]. While in the GDPbound state the GTPase is inactive. Activation of the GEFs, typically by tyrosine kinase growth factor receptors, leads to exchange of the GDP for GTP, thus activating the GTPase (reviewed in [79]). Binding of GTP produces a conformational change in the GTPase allowing interaction with downstream effector proteins [72, 79-81]. Hydrolysis of GTP to GDP by the intrinsic GTPase action activates the effector protein that leads to downstream signals and a cellular response [72]. The interaction between Rho (A-C) GTPase and downstream effectors is functionally inhibited by $\mathrm{C} 3$ exotransferase, which ADP-ribosylates asparagine 41 of the GTPase [30]. Activation of GAPs catalyzes hydrolysis of GTP to GDP, thus inactivating the GTPase and terminating the interaction with downstream effector proteins, thereby closing the cycle [72, $82,83]$.

\section{The potential role of Rho-regulatory proteins in breast cancer cell motility}

\section{Rho GDP dissociation inhibitors (RhoGDIs)}

Like Ras, the Rho GTPases are post-translationally modified to locate them to their distinct cell compartment so they can carry out their specific function $[25,84,85]$. Each Rho protein contains a C-terminal CAAX domain that determines prenylation and polybasic residues in the hypervariable domain, upstream of the CAAX domain, which dictate proper membrane localization [85].

Localization and trafficking of the Rho GTPases to the cell membrane is a complex phenomenon. GDPbound Rho is prenylated and bound at the prenylation site by specific RhoGDIs until liberated by RhoGDF, transported to its specific membrane location and activated by RhoGEF [75-78]. The type of prenylation is Rho protein dependent. RhoA and RhoC GTPase are geranylgeranylated, while RhoB can either be geranylgeranylated or farnesylated $[42,85]$.

Many investigators working on the GDIs believe that these proteins function to inhibit Rho activity by 'isolating' Rho proteins at two distinct points, (1) by directly preventing the exchange of GDP for GTP by the GEFs and (2) by preventing intrinsic and RhoGAP mediated GTP hydrolysis [86]. Several lines of investigation support this idea. Microinjection of RhoGDI into immortalized fibroblasts can significantly inhibit their motility [87]. Similar results are 
achieved when RhoGDIs are overexpressed in human keratinocytes, leading to disruption of the actin cytoskeleton and inhibition of motility [88].

Thus, since they function to inhibit Rho activity and subsequently cellular motility, the RhoGDIs are attractive candidates for regulating the activity of Rho proteins in breast cancer cells. RhoGDI $\alpha$ overexpression has been shown to increase $\operatorname{ER} \alpha, \operatorname{ER} \beta$, androgen and glucocorticoid receptor transcriptional activation in mammalian cells [89]. Conversely, expression of activated RhoA, Rac1 or Cdc42 lead to repression of ER transcriptional levels [89]. Expression and activation of ER $\alpha$ and ER $\beta$ directly inhibits MDA-MB-231 breast cancer cell motility and invasion [90]. These data therefore suggest that RhoGDIs can enhance ER transcription and breast cancer cell motility through inhibition of Rho activity.

Prendergast et al. have demonstrated that geranylgeranylated RhoB has tumor suppressor effects on cancer cells [91-95]. Treatment of tumor cells with a farnesyl transferase inhibitor (FTI) leads to a decrease in farnesylated RhoB levels and a corresponding increase in geranylgeranylated RhoB levels [91-95]. This effect is extended to RhoC overexpressing cells [71]. FTI treatment of RhoC overexpressing HME or SUM149 IBC cells leads to a marked decrease in their motility and invasiveness. Presumably, FTI treatment allows more geranylgeranylated RhoB to be available for localization to the cell membrane, leaving GDIbound RhoC sequestered in the cytoplasm remaining unavailable to the GEFs and GAPs.

\section{Rho guanine exchange factors (RhoGEFs)}

Because of their ability to catalyze the exchange of GDP for GTP, coupled with their susceptibility to acquire activating mutations, the RhoGEFs are probably the best candidates for aberrant GTPase activation in human cancer $[79,96]$. The first RhoGEF to be identified in human cancer was the Dbl proto-oncogene. Dbl was isolated during an attempt to clone unique transforming factors from human B-cell lymphomas and was found to be homologous to $\mathrm{Cdc} 24$, a $\mathrm{Cdc} 42$ specific RhoGEF found in yeast [96, 97]. Analysis of Dbl demonstrated that mutations within the RhoGEF could lead to constitutive activation of the GEF and cellular transformation [97].

Since the discovery of Dbl, many Ras and RhoGEFS have been identified due to their transforming abilities. This growing family of proto-oncogenes is identified by their structural similarity. The Dbl-like
RhoGEFs have an autoinhibitory domain to prevent GDP/GTP exchange from occurring aberrantly [98, 99]. Upon phosphorylation and activation by protein tyrosine kinases or tyrosine kinase receptors, the autoinhibitory domain is released and the RhoGEF is activated. In the case of oncogenic RhoGEFs, such as the Vav proto-oncogene, an activating mutation results in deletion of the phosphorylation site and destruction of the autoinhibitory mechanism [99].

All GEFs contain a conserved $\sim 150$ amino acid Dbl-homology (DH) domain immediately followed by an $\sim 100$ amino acid pleckstrin-homology $(\mathrm{PH})$ domain (reviewed in $[100,101])$. Since the first descriptions of $\mathrm{Cdc} 24$ in yeast and Dbl in humans, a very large family of potential Ras- and RhoGEF proteins has been identified over the years, all of which contain the DH-PH domain and therefore comprise the largest known family of proto-oncogenes.

It is the DH-PH domains that allow the GEFs to interact with other molecules such as the Ras- and Rho-GTPases and effect diverse cellular functions. The PH domain binds to phosphoinositides, possibly targeting the GEF to its cellular location [102]. The $\mathrm{PH}$ domain also may regulate interactions with other molecules and is essential in cellular transformation by oncogenic GEF molecules [103-105]. It is the DH domain that dictates the specificity of the RhoGEF for single or multiple Rho proteins and allows the GEF to interact with molecules other than the GTPases that affect the arrangement of the actin cytoskeleton [100]. A classic example is Trio, a Rac1- and RhoGGEF, which can induce membrane ruffling in cells by directly interacting with filamin, an actin filament crosslinking protein [103].

In addition to their interaction with GTPases and actin-associated molecules, the GEFs can interact with and be activated by several intrinsic kinases and protein tyrosine kinase growth factor receptors [79, 104, 106-109]. Several GEFs catalyze the exchange of GDP for GTP in response to stimulation from growth factors such as epidermal growth factor (EGF). Again, the Vav family of RhoGEFs is an example of a group of GEFs that are activated in response to growth factor stimulation, particularly from the epidermal growth factor receptor (EGFR) [110-113]. Coupled with the fact that EGFR is typically overexpressed in IBC, the Vav proteins make attractive candidates for the activation of RhoC in IBC cells [64]. This group of GEFs consists of three family members, which can interact with RhoA, Rac1 and Cdc42 [112-114]. Vav1 is found primarily in hematopoietic cells, but may 
be involved in human breast cancer, while Vav2 and Vav3 are expressed ubiquitously in tissues [112-114]. Protein tyrosine kinase receptors, such as EGFR can stimulate each of the Vav protein members leading to Rho-GTPase activation, cytoskeletal reorganization and cellular motility [110-113]. Although their interaction with RhoC has not been explored, the Vav family of RhoGEFs is an exciting potential control point for regulating the diverse actions of the RhoC phenotype in breast cancer.

\section{Rho GTPase activating proteins (RhoGAPs)}

As outlined above, intrinsic kinases and growth factors receptors participate in the modulation of the GTPase cycle by activating the GEFs, but they also effect GAP activity. Ras and Rho GTPases can inactivate themselves through an intrinsic GTPase activity that hydrolyzes GTP to GDP. The kinetics of this reaction is greatly increased by GAP proteins [83, 115, 116]. For example, hydrolysis of RhoA-GTP to RhoA-GDP catalyzed by p190 RhoGAP is increased by 4000 -fold over RhoA-self mediated conversion [117].

The p190 protein is probably the best studied and described of the RhoGAPs. p190 was first identified as a phosphorylated protein associated with p120 RasGAP in v-Src-transformed, growth factor stimulated cells [118]. Two isoforms of p190 exist, the more commonly studied p190-B and the putative tumor suppressor gene, p190-A [119, 120]. Comparing the GAP-domains of several putative RhoGAP proteins, Ridley et al. demonstrated that p190 was a Rho-specific GAP that induced actin cytoskeletal reorganization [115]. p190 was found to have three distinct functional domains; a N-terminal GTPase domain that binds GDP/GTP in a similar fashion to Ras and Rho, a middle domain (MD), which upon tyrosine phosphorylation is responsible for binding to a $\mathrm{SH} 3$ ( $\mathrm{Src}$ homology 3) domain flanked by two $\mathrm{SH} 2$ domains on p120 RasGAP and a C-terminal GAP domain responsible for inactivation of GTP-bound Rho [115, 121-124].

Functional experiments demonstrated that inhibition of p190 leads to actin cytoskeletal reorganization in 3 T3 cells [125]. Treatment of cultured fibroblasts with sodium fluoride $(\mathrm{NaF})$ promoted the formation of a high affinity complex between the Rho GTPases and p190 RhoGAP. This effectively sequesters p190, which is found in limiting concentrations in the cell, and results in Rho activation. Furthermore, it was demonstrated that treatment with low dose $\mathrm{NaF}$ and lysophosphatidic acid (LPA), inhibited GAP activity while stimulating GEF activity, further increasing Rho activation. These findings suggests that inactivation of Rho by $\mathrm{p} 190$ is essential for impeding constitutive Rho activity and that the Rho GTPases are regulated by a fine balance between inactivation by the GAPs and activation by the GEFs.

Because p190 was first identified in Src transformed cells, Fincham et al. addressed the role of p190 in v-Src-mediated cytoskeletal reorganization of chicken embryo fibroblasts [126]. They found that activation of a temperature-dependent $\mathrm{v}$-Src kinase induced tyrosine phosphorylation of p190 RhoGAP leading to association p120 RasGAP [126]. Switching off $\mathrm{v}$-Src led to the dissociation of the p190/p120 heterodimer and the reformation of actin stress fibers common to non-motile cells. Introduction of a constitutively active RhoA mutant (Val14-RhoA), in the presence of activated $\mathrm{v}$-Src, also led to reformation of actin stress fibers.

Many sites within all three domains of p190 RhoGAP can be phosphorylated and it is speculated that kinases, such as c-Src and v-Src, and growth factors utilize multiple sites to modulate a variety of GAP activities. In vitro phosphorylation of the N-terminal domain of p190 by c-Src, resulted in a marked decrease in the ability of the GAP to directly bind GTP [106]. While phosphorylation of tyrosine residue 1105 in the MD was identified as the main site for c-Src mediated p190/p120 heterodimer formation [127]. These observations were furthered by Haskell et al. who demonstrated that the MD and GAP domains of p190 specifically regulate heterodimer formation and Rho activity and actin reorganization in response to c-Src transformation and EGF stimulation [128].

Roof et al. demonstrated that EGF induced phosphorylation of tyrosine 1105 of p190 RhoGAP was required for heterodimer formation with p120 RasGAP leading to a loss in GTP-binding, decreased GTP hydrolysis and actin reorganization [127]. At the time of EGF activation, the p190 and p120 are located at the inner plasma membrane [129]. Upon heterodimer formation, the p190/p120 complex becomes associated with EGFR in an endocytic compartment and is internalized [129].

The role of p190 RhoGAP in cell motility was investigated using fibroblasts isolated from p120 null mouse embryos that lack the ability to polarize and move in a wound assay [130]. Reintroduction of wild-type p120 into the cells restored their ability to 
polarize and undergo directional motility in a p190/120 heterodimer dependent manner. Microinjection of the p190 MD domain into the motile cells disrupted heterodimer formation leading to inhibition of polarity and motility. Similarly, cellular aggregation occurs during engagement of E-cadherin and phosphorylation of $\mathrm{p} 120$, presumably on a unique tyrosine residue, without p190 heterodimer formation [131].

The vast majority of data detailing the function of p190 RhoGAP in cellular motility has come from studies in fibroblasts. However, recent data suggests that the p190/p120 heterodimer may play a role in breast cancer motility and metastasis. Zhrihan-Licht et al. demonstrated that stimulation of human breast cancer cell lines by heregulin leads to the formation of multiprotein complex and phosphorylation of RAFTK, a focal adhesion-related kinase [132]. Upon analysis they determined that the complex consisted of RAFTK, Her2/Neu, p190 RhoGAP, and p120 RasGAP. They also demonstrated that RAFTK, which contains an internal Src binding domain, was found to mediate Src phosphorylation of $\mathrm{p} 190$, and increase breast cancer cell invasion.

\section{GAPs in IBC cells}

A plausible hypothesis on the role of p190 RhoGAP and p120 RasGAP in RhoC-mediated IBC cell motility can be formulated from the observations presented above. EGFR amplification or Her2/Neu expression leads to tyrosine phosphorylation and activation of p190 RhoGAP and or p120 RasGAP. In turn, p190 associates with p120 RasGAP forming a heterodimer, which colocalizes in endocytic membrane compartments with the activated EGFR or Her2/neu. This prevents either GAP from dephosphorylating and inactivating their respective GTPase, thus prolonging GTPase activity, cellular motility and invasion. Western blot analysis of $20 \mu \mathrm{g}$ protein isolated from HME and SUM149 IBC cells demonstrated expression of p120 in both cell lines grown under normal conditions (Figure 4(A)) [54]. The SUM149 cells expressed higher levels of p120, but also expressed a $100 \mathrm{kDa}$ protein. Similarly, the SUM149 cell line expressed significantly higher levels of p190 than the HME cells (Figure 4(B)). This result is consistent with observations made in spontaneous potentially aggressive murine mammary tumors [133].
To explore the hypothesis that p120 and p190 may interact in human IBC cells, we performed immunoprecipitations of p190 followed by immunoblotting for $\mathrm{p} 120$. We also performed the reciprocal immunoprecipitation using an antibody to p120 followed by immunoblotting for $\mathrm{p} 190$. Protein lysates were harvested from HME and SUM149 IBC cells serum/growth factor-starved for $16 \mathrm{~h}$ and then either left unstimulated or stimulated for $1 \mathrm{~h}$ with $10 \%$ fetal bovine serum.

Surprisingly, immunoprecipitation of $500 \mu \mathrm{g}$ of protein using a p190 antibody followed by immunoblotting for p120 did not demonstrate the predicted $120 \mathrm{kDa}$ band, but rather a band at $100 \mathrm{kDa}$ (Figure $4(\mathrm{C})$ ). The $100 \mathrm{kDa}$ band was consistently expressed in the HME cells, whether the cells were grown under serum/growth factor-free conditions or serum stimulated. In contrast, the $100 \mathrm{kDa}$ band was strongly associated with p190 in the SUM149 cells grown under serum-free conditions. After $1 \mathrm{~h}$ serum stimulation, p100 associated with p190 was almost undetectable. Upon examination of the literature, we found that p120 RasGAP can exist in two forms, Type I RasGAP, which is found to be $120 \mathrm{kDa}$ in size and an alternatively spliced $100 \mathrm{kDa}$ Type II form [134-136]. Expression of the Type II $100 \mathrm{kDa}$ form of RasGAP has previously been thought to be restricted to placental trophoblasts, choriocarcinoma cells and leukemic cells [134-138]. This is the first report of this protein being involved in human breast cancer cells.

Even more interesting was the identification of a $105 \mathrm{kDa}$ protein in the serum stimulated SUM149 IBC cells (Figure 4(D)). Expression of this protein was not seen in the serum starved SUM149 and barely detectable in serum starved or stimulated HME cells. Since the $105 \mathrm{kDa}$ protein was detected by an antibody raised against the middle and GAP domain of rat p190 RhoGAP, these data suggests that this is new RhoGAP. Again, a review of the literature yielded a single paper describing a $105 \mathrm{kDa}$ RasGAP associated protein [137]. The authors of this paper, Ye et al. identified, but did not clone or sequence a novel $105 \mathrm{kDa}$ protein associated with p120 Type I and p100 Type II RasGAP in human trophoblasts and choriocarcinoma cells that were induced to differentiate with okadaic acid [137].

Taken together, our data suggest that p105 and p100 may be the GAPs involved in regulating RhoC GTPase activity in RhoC overexpressing IBC cells. We are currently cloning and characterizing p105 in our IBC cells. 
(A)

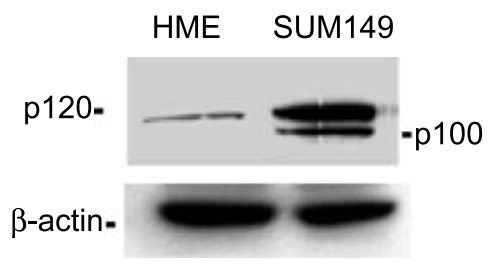

I.B. $=\alpha p 120$

(B)

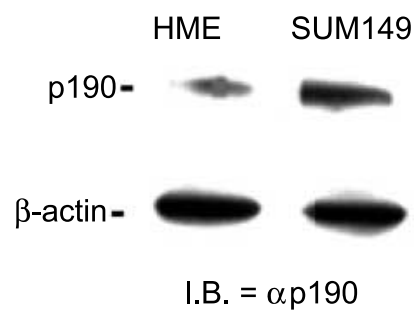

SUM149

SFM $10 \%$ FBS. SFM $10 \%$ FBS.

(C)

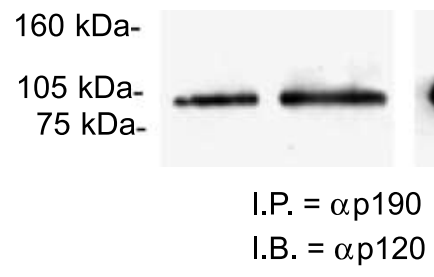

(D)

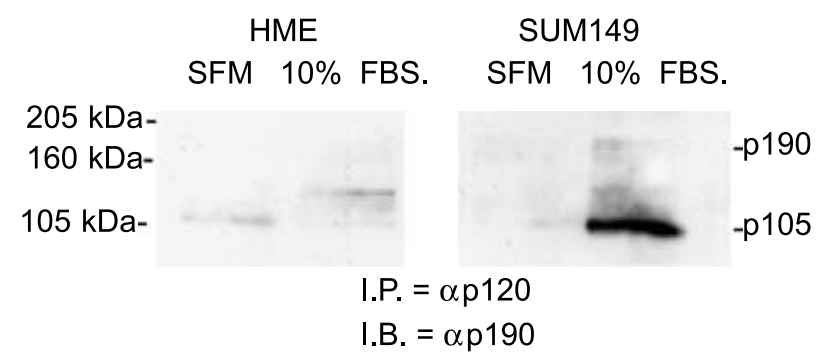

Figure 4. Results of immunoprecipitations and western blot analysis of Rho and Ras GAPs in IBC cells. Panels A and B are western blots for p120 RasGAP and p190 RhoGAP, respectively, in HME and SUM149 cells at 70\% confluence grown under normal conditions. An antibody specific for p120 RasGAP (Upstate Biotechnology cat. No. 5-178) was used to detect p120 in $20 \mu \mathrm{g}$ protein. The p120 RasGAP was detected in both the HME and SUM149 cells however an alternatively spliced form was detected at p100. Higher levels of p120 were detected in the SUM149 IBC cells. Similarly, p190 RhoGAP was detected in both the HME and SUM149 cells using a monoclonal antibody directed to the GAP domain of p190 (Upstate Biotechnology cat. No. 05-378). Higher levels of p190 were detected in the SUM149 IBC cells than the HME cells. $\beta$-actin was used as a loading control. The interaction between p120 and p190 was analyzed in HME and SUM149 cells grown under serum/growth factor-free (SFM) conditions or serum (10\% MEM) stimulated for $1 \mathrm{~h}$. Panel C is the result of an immunoprecipitation using the p190 antibody followed by immunoblotting with the p120 antibody. No p120 was detected in either cell line regardless of growth condition, rather the p100 form of RasGAP was detected. The levels of p100 were slightly higher in the serum stimulated HME cells than those grown in SFM. Levels of p100 were high in the SUM149 cells grown in SFM but disappeared after serum stimulation. In the reciprocal immunoprecipitation using a p120 antibody followed by immunoblotting with a p190 antibody (Panel D), p190 was detected in the SUM149 serum stimulated cells. More interestingly, a strong band was detected at p105 in the SUM149 serum stimulated cells.

\section{Challenges for the future}

Interest in Rho GTPase expression, as it pertains to the progression of breast and other cancers, has increased dramatically over the past half decade. Elucidating the mechanisms that result in Rho-overexpression and activation are key in understanding the role of these proteins in breast cancer progression and metastasis. It is apparent that a delicate equipoise between the Rhoregulatory proteins exists. This fine balance keeps the
Rho GTPases in equilibrium between an inactive and active state. Plainly, perturbation of any of the Rhoregulatory proteins, either through mutation, growth factor receptor dysregulation or oncogene expression can lead to aberrant Rho activation, increased motility, invasion and possibly metastasis. With the large number of RhoGDIs, RhoGEFs and RhoGAPs thus far identified, and more being continuously added to the list, the main challenge will be to find the key molecules involved in Rho-dysregulation. 


\section{Acknowledgements}

Work supported by grants DAMD 17-00-1-0637 and DAMD 17-03-1-0728 from the Department of Defense and by 5 P30 CA46592 from the NIH.

\section{References}

1. Fidler IJ: Critical factors in the biology of human cancer metastasis: twenty-eighth G.H.A. Clowes memorial award lecture. Cancer Res 50: 6130-6138, 1990

2. Cancer Management: A Multidisciplinary Approach. PPR, Inc., Melville, NY, 1999

3. Aukerman SL, Price JE, Fidler IJ: Different deficiencies in the prevention of tumorigenic-low-metastatic murine $\mathrm{K}$ $1735 \mathrm{~b}$ melanoma cells from producing metastases. J Natl Cancer Inst 77: 915-924, 1986

4. Price JE, Aukerman SL, Fidler IJ: Evidence that the process of murine melanoma metastasis is sequential and selective and contains stochastic elements. Cancer Res 46: 5172-5178, 1986

5. Pathak S, Staroselsky AN, Fidler IJ: Specific chromosomal defects associated with metastatic potential in K-1735 melanoma clones. Involvement of chromosomes 4 and 14. Cancer Genet Cytogenet 56: 209-221, 1991

6. Takai Y, Sasaki T, Matozaki T: Small GTP-binding proteins. Physiol Rev 81: 153-208, 2001

7. Kjoller L, Hall A: Signaling to Rho GTPases. Exp Cell Res 253: 166-179, 1999

8. Sahai E, Marshall CJ: RHO-GTPases and cancer. Nat Rev Cancer 2: 133-142, 2002

9. Sander EE, ten Klooster JP, van Delft S, van der Kammen RA, Collard JG: Rac downregulates Rho activity: reciprocal balance between both GTPases determines cellular morphology and migratory behavior. J Cell Biol 147: 1009-1022, 1999

10. del Peso L, Hernandez-Alcoceba R, Embade N, Carnero A, Esteve P, Paje C, Lacal JC: Rho proteins induce metastatic properties in vivo. Oncogene 15: 3047-3057, 1997

11. Zondag GC, Evers EE, ten Klooster JP, Janssen L, van der Kammen RA, Collard JG: Oncogenic Ras downregulates Rac activity, which leads to increased Rho activity and epithelialmesenchymal transition. J Cell Biol 149: 775-782, 2000

12. Frost JA, Steen H, Shapiro P, Lewis T, Ahn N, Shaw PE, Cobb MH: Cross-cascade activation of ERKs and ternary complex factors by Rho family proteins. EMBO J 16 : 6426-6438, 1997

13. Li W, Chong H, Guan KL: Function of the Rho family GTPases in Ras-stimulated Raf activation. J Biol Chem 276: 34728-34737, 2001

14. van Golen KL, Bao LW, Pan Q, Miller FR, Wu ZF, Merajver $\mathrm{SD}$ : Mitogen activated protein kinase pathway is involved in RhoC GTPase induced motility, invasion and angiogenesis in inflammatory breast cancer. Clin Exp Metast 19: 301-311, 2002

15. Danen EH, Sonneveld P, Sonnenberg A, Yamada KM: Dual stimulation of Ras/mitogen-activated protein kinase and RhoA by cell adhesion to fibronectin supports growth factor-stimulated cell cycle progression. J Cell Biol 151: 1413-1422, 2000

16. Wittmann T, Waterman-Storer CM: Cell motility: can Rho GTPases and microtubules point the way? J Cell Sci 114: 3795-3803, 2001
17. Ridley AJ: Rho family proteins: coordinating cell responses. Trends Cell Biol 11: 471-477, 2001

18. Madaule P, Axel R: A novel ras-related gene family. Cell 41: 31-40, 1985

19. Ridley AJ, Hall A: The small GTP-binding protein rho regulates the assembly of focal adhesions and actin stress fibers in response to growth factors. Cell 70: 389-399, 1992

20. Ridley AJ, Paterson HF, Johnston CL, Diekmann D, Hall A: The small GTP-binding protein rac regulates growth factor-induced membrane ruffling. Cell 70: 401-410, 1992

21. Nobes CD, Hall A: Rho, rac, and cdc42 GTPases regulate the assembly of multimolecular focal complexes associated with actin stress fibers, lamellipodia, and filopodia. Cell 81: 53-62, 1995

22. Ridley AJ, Hall A: Distinct patterns of actin organization regulated by the small GTP-binding proteins Rac and Rho. Cold Spring Harb Symp Quant Biol 57: 661-671, 1992

23. Kozma R, Ahmed S, Best A, Lim L: The Ras-related protein $\mathrm{Cdc} 42 \mathrm{Hs}$ and bradykinin promote formation of peripheral actin microspikes and filopodia in Swiss 3 T3 fibroblasts. Mol Cell Biol 15: 1942-1952, 1995

24. Wherlock M, Mellor H: The Rho GTPase family: a Racs to Wrchs story. J Cell Sci 115: 239-240, 2002

25. Hori Y, Kikuchi A, Isomura M, Katayama M, Miura Y, Fujioka H, Kaibuchi K, Takai Y: Post-translational modifications of the C-terminal region of the rho protein are important for its interaction with membranes and the stimulatory and inhibitory GDP/GTP exchange proteins. Oncogene 6: 515-522, 1991

26. Dallery E, Galiegue-Zouitina S, Collyn-d'Hooghe M, Quief S, Denis C, Hildebrand MP, Lantoine D, Deweindt C, Tilly $\mathrm{H}$, Bastard C: TTF, a gene encoding a novel small G protein, fuses to the lymphoma-associated LAZ3 gene by $\mathrm{t}(3 ; 4)$ chromosomal translocation. Oncogene 10: 2171-2178, 1995

27. Nobes CD, Lauritzen I, Mattei MG, Paris S, Hall A, Chardin P: A new member of the Rho family, Rnd1, promotes disassembly of actin filament structures and loss of cell adhesion. J Cell Biol 141: 187-197, 1998

28. Dallery-Prudhomme E, Roumier C, Denis C, Preudhomme C, Kerckaert JP, Galiegue-Zouitina S: Genomic structure and assignment of the RhoH/TTF small GTPase gene (ARHH) to 4p13 by in situ hybridization. Genomics 43: 89-94, 1997

29. Fritz G, Kaina B, Aktories K: The ras-related small GTPbinding protein RhoB is immediate-early inducible by DNA damaging treatments. J Biol Chem 270: 25172-25177, 1995

30. Aktories K: Rho proteins: targets for bacterial toxins. Trends Microbiol 5: 282-288, 1997

31. Aktories K, Hall A: Botulinum ADP-ribosyltransferase C3: a new tool to study low molecular weight GTP-binding proteins. Trends Pharmacol Sci 10: 415-418, 1989

32. Aktories K, Braun U, Rosener S, Just I, Hall A: The rho gene product expressed in E. coli is a substrate of botulinum ADPribosyltransferase C3. Biochem Biophys Res Commun 158: 209-213, 1989

33. Paterson HF, Self AJ, Garrett MD, Just I, Aktories K, Hall A: Microinjection of recombinant $\mathrm{p} 21$ rho induces rapid changes in cell morphology. J Cell Biol 111: 1001-1007, 1990

34. Hall A: The cellular functions of small GTP-binding proteins. Science 249: 635-640, 1990

35. Hall A: Rho GTPases and the actin cytoskeleton. Science 279: 509-514, 1998

36. Ridley AJ: Membrane ruffling and signal transduction. Bioessays 16: 321-327, 1994 
37. Price LS, Collard JG: Regulation of the cytoskeleton by Rho-family GTPases: implications for tumour cell invasion. Semin Cancer Biol 11: 167-173, 2001

38. Evers EE, van der Kammen RA, ten Klooster JP, Collard JG: Rho-like GTPases in tumor cell invasion. Methods Enzymol 325: 403-415, 2000

39. Gampel A, Parker PJ, Mellor H: Regulation of epidermal growth factor receptor traffic by the small GTPase rhoB. Curr Biol 9: 955-958, 1999

40. Esteve P, Embade N, Perona R, Jimenez B, del Peso L, Leon J, Arends M, Miki T, Lacal JC: Rho-regulated signals induce apoptosis in vitro and in vivo by a p53-independent, but $\mathrm{Bcl} 2$ dependent pathway. Oncogene 17: 1855-1869, 1998

41. Coleman ML, Olson MF: Rho GTPase signalling pathways in the morphological changes associated with apoptosis. Cell Death Differ 9: 493-504, 2002

42. Cussac D, Leblanc P, L'Heritier A, Bertoglio J, Lang P, Kordon C, Enjalbert A, Saltarelli D: Rho proteins are localized with different membrane compartments involved in vesicular trafficking in anterior pituitary cells. Mol Cell Endocrinol 119: 195-206, 1996

43. Hall A, Marshall CJ, Spurr NK, Weiss RA: Identification of transforming gene in two human sarcoma cell lines as a new member of the ras gene family located on chromosome 1. Nature 303: 396-400, 1983

44. Brown R, Marshall CJ, Pennie SG, Hall A: Mechanism of activation of an N-ras gene in the human fibrosarcoma cell line HT1080. EMBO J 3: 1321-1326, 1984

45. McGrath JP, Capon DJ, Smith DH, Chen EY, Seeburg PH, Goeddel DV, Levinson AD: Structure and organization of the human Ki-ras proto-oncogene and a related processed pseudogene. Nature 304: 501-506, 1983

46. Capon DJ, Seeburg PH, McGrath JP, Hayflick JS, Edman $\mathrm{U}$, Levinson AD, Goeddel DV: Activation of Ki-ras2 gene in human colon and lung carcinomas by two different point mutations. Nature 304: 507-513, 1983

47. Feramisco JR, Gross M, Kamata T, Rosenberg M, Sweet RW: Microinjection of the oncogene form of the human H-ras (T24) protein results in rapid proliferation of quiescent cells. Cell 38: 109-117, 1984

48. Stacey DW, Kung HF: Transformation of NIH 3T3 cells by microinjection of Ha-ras p21 protein. Nature 310: 508-511, 1984

49. Rodenhuis S: ras and human tumors. Semin Cancer Biol 3: 241-247, 1992

50. Rochlitz CF, Scott GK, Dodson JM, Liu E, Dollbaum C, Smith HS, Benz CC: Incidence of activating ras oncogene mutations associated with primary and metastatic human breast cancer. Cancer Res 49: 357-360, 1989

51. Fritz G, Just I, Kaina B: Rho GTPases are over-expressed in human tumors. Int J Cancer 81: 682-687, 1999

52. Moscow JA, He R, Gnarra JR, Knutsen T, Weng Y, Zhao WP, Whang-Peng J, Linehan WM, Cowan KH: Examination of human tumors for rhoA mutations. Oncogene 9: 189-194, 1994

53. van Golen KL, Wu ZF, Qiao XT, Bao LW, Merajver SD: RhoC GTPase, a novel transforming oncogene for human mammary epithelial cells that partially recapitulates the inflammatory breast cancer phenotype. Cancer Res 60: 5832-5838, 2000

54. van Golen KL, Davies S, Wu ZF, Wang Y, Bucana CD, Root H, Chandrasekharappa S, Strawderman M, Ethier SP, Merajver SD: A novel putative low-affinity insulin-like growth factor-binding protein, LIBC (lost in inflammatory breast cancer), and RhoC GTPase correlate with the in- flammatory breast cancer phenotype. Clin Cancer Res 5: 2511-2519, 1999

55. Imamura F, Mukai M, Ayaki M, Takemura K, Horai T, Shinkai K, Nakamura H, Akedo H: Involvement of small GTPases Rho and Rac in the invasion of rat ascites hepatoma cells. Clin Exp Metast 17: 141-148, 1999

56. Clark EA, Golub TR, Lander ES, Hynes RO: Genomic analysis of metastasis reveals an essential role for RhoC. Nature 406: 532-535, 2000

57. Avraham H: rho gene amplification and malignant transformation. Biochem Biophys Res Commun 168: 114-124, 1990

58. Avraham H, Weinberg RA: Characterization and expression of the human rhoH12 gene product. Mol Cell Biol 9: 2058-2066, 1989

59. Perona R, Esteve P, Jimenez B, Ballestero RP, Cajal S, Lacal JC: Tumorigenic activity of rho genes from Aplysia californica. Oncogene 8: 1285-1292, 1993

60. Prendergast GC, Khosravi-Far R, Solski PA, Kurzawa H, Lebowitz PF, Der CJ: Critical role of Rho in cell transformation by oncogenic Ras. Oncogene 10: 2289-2296, 1995

61. Rihet S, Vielh P, Camonis J, Goud B, Chevillard S, de Gunzburg J: Mutation status of genes encoding RhoA, Rac1, and Cdc42 GTPases in a panel of invasive human colorectal and breast tumors. J Cancer Res Clin Oncol 127: 733-738, 2001

62. Bouzahzah B, Albanese C, Ahmed F, Pixley F, Lisanti MP, Segall JD, Condeelis J, Joyce D, Minden A, Der CJ, Chan A, Symons M, Pestell RG: Rho family GTPases regulate mammary epithelium cell growth and metastasis through distinguishable pathways. Mol Med 7: 816-830, 2001

63. Jo M, Thomas KS, Somlyo AV, Somlyo AP, Gonias SL: Cooperativity between the Ras-ERK and Rho-Rho kinase pathways in urokinase-type plasminogen activator-stimulated cell migration. J Biol Chem 277: 12479-12485, 2002

64. Kleer CG, van Golen KL, Merajver SD: Molecular biology of breast cancer metastasis. Inflammatory breast cancer: clinical syndrome and molecular determinants. Breast Cancer Res 2: 423-429, 2000

65. Jaiyesimi IA, Buzdar AU, Hortobagyi G: Inflammatory breast cancer: a review. J Clin Oncol 10: 1014-1024, 1992

66. Tabbane F, el May A, Hachiche M, Bahi J, Jaziri M, Cammoun M, Mourali N: Breast cancer in women under 30 years of age. Breast Cancer Res Treat 6: 137-144, 1985

67. Levine PH, Steinhorn SC, Ries LG, Aron JL: Inflammatory breast cancer: the experience of the surveillance, epidemiology, and end results (SEER) program. J Natl Cancer Inst 74: 291-297, 1985

68. Kleer CG, van Golen KL, Zhang Y, Wu ZF, Rubin MA, Merajver SD: Characterization of RhoC expression in benign and malignant breast disease: a potential new marker for small breast carcinomas with metastatic ability. Am J Pathol 160: 579-584, 2002

69. van Golen KL, Wu ZF, Qiao XT, Bao L, Merajver SD: RhoC GTPase overexpression modulates induction of angiogenic factors in breast cells. Neoplasia 2: 418-425, 2000

70. Diekmann D, Hall A: In vitro binding assay for interactions of Rho and Rac with GTPase-activating proteins and effectors. Methods Enzymol 256: 207-215, 1995

71. van Golen KL, Bao LW, DeVito MM, Wu ZF, Prendergast GC, Merajver SD: Reversion of RhoC GTPase induced transformation in inflammatory breast cancer cells by treatmen with farnesyl transferase inhibitor. Mol Cancer Therapeutics (in press) 
72. Olson MF: Guanine nucleotide exchange factors for the Rho GTPases: a role in human disease? J Mol Med 74: 563-571, 1996

73. Geyer M, Wittinghofer A: GEFs, GAPs, GDIs and effectors: taking a closer (3D) look at the regulation of Ras-related GTP-binding proteins. Curr Opin Struct Biol 7: 786-792, 1997

74. Prokopenko SN, Saint R, Bellen HJ: Untying the Gordian knot of cytokinesis. Role of small $\mathrm{G}$ proteins and their regulators. J Cell Biol 148: 843-848, 2000

75. Olofsson B: Rho guanine dissociation inhibitors: pivotal molecules in cellular signalling. Cell Signal 11: 545-554, 1999

76. Scheffzek K, Stephan I, Jensen ON, Illenberger D, Gierschik P: The Rac-RhoGDI complex and the structural basis for the regulation of Rho proteins by RhoGDI. Nat Struct Biol 7: 122-126, 2000

77. Michaelson D, Silletti J, Murphy G, D'Eustachio P, Rush M, Philips MR: Differential localization of Rho GTPases in live cells: regulation by hypervariable regions and RhoGDI binding. J Cell Biol 152: 111-126, 2001

78. Mondal MS, Wang Z, Seeds AM, Rando RR: The specific binding of small molecule isoprenoids to rhoGDP dissociation inhibitor (rhoGDI). Biochemistry 39: 406-412, 2000

79. Overbeck AF, Brtva TR, Cox AD, Graham SM, Huff SY, Khosravi-Far R, Quilliam LA, Solski PA, Der CJ: Guanine nucleotide exchange factors: activators of Ras superfamily proteins. Mol Reprod Dev 42: 468-476, 1995

80. Bishop AL, Hall A: Rho GTPases and their effector proteins. Biochem J 348(Pt 2): 241-255, 2000

81. Quilliam LA, Khosravi-Far R, Huff SY, Der CJ: Guanine nucleotide exchange factors: activators of the Ras superfamily of proteins. Bioessays 17: 395-404, 1995

82. Scheffzek K, Ahmadian MR, Wittinghofer A: GTPaseactivating proteins: helping hands to complement an active site. Trends Biochem Sci 23: 257-262, 1998

83. Gamblin SJ, Smerdon SJ: GTPase-activating proteins and their complexes. Curr Opin Struct Biol 8: 195-201, 1998

84. Kirschmeier PT, Whyte D, Wilson O, Bishop WR, Pai JK: In vivo prenylation analysis of Ras and Rho proteins. Methods Enzymol 332: 115-127, 2001

85. Adamson P, Marshall CJ, Hall A, Tilbrook PA: Posttranslational modifications of $\mathrm{p} 21$ rho proteins. J Biol Chem 267: 20033-20038, 1992

86. Adra CN, Manor D, Ko JL, Zhu S, Horiuchi T, Van Aelst L, Cerione RA, Lim B: RhoGDIgamma: a GDP-dissociation inhibitor for Rho proteins with preferential expression in brain and pancreas. Proc Natl Acad Sci USA 94: 4279-4284, 1997

87. Miura Y, Kikuchi A, Musha T, Kuroda S, Yaku H, Sasaki T, Takai Y: Regulation of morphology by rho p21 and its inhibitory GDP/GTP exchange protein (rho GDI) in Swiss 3 T3 cells. J Biol Chem 268: 510-515, 1993

88. Leffers H, Nielsen MS, Andersen AH, Honore B, Madsen $\mathrm{P}$, Vandekerckhove J, Celis JE: Identification of two human Rho GDP dissociation inhibitor proteins whose overexpression leads to disruption of the actin cytoskeleton. Exp Cell Res 209: 165-174, 1993

89. Su LF, Knoblauch R, Garabedian MJ: Rho GTPases as modulators of the estrogen receptor transcriptional response. J Biol Chem 276: 3231-3237, 2001

90. Lazennec G, Bresson D, Lucas A, Chauveau C, Vignon F: ER beta inhibits proliferation and invasion of breast cancer cells. Endocrinology 142: 4120-4130, 2001

91. Lebowitz PF, Davide JP, Prendergast GC: Evidence that farnesyltransferase inhibitors suppress Ras transformation by interfering with Rho activity. Mol Cell Biol 15: 6613-6622, 1995

92. Lebowitz PF, Casey PJ, Prendergast GC, Thissen JA: Farnesyltransferase inhibitors alter the prenylation and growth-stimulating function of RhoB. J Biol Chem 272: 15591-15594, 1997

93. Du W, Lebowitz PF, Prendergast GC: Cell growth inhibition by farnesyltransferase inhibitors is mediated by gain of geranylgeranylated RhoB. Mol Cell Biol 19: 1831-1840, 1999

94. Liu A, Prendergast GC: Geranylgeranylated RhoB is sufficient to mediate tissue-specific suppression of Akt kinase activity by farnesyltransferase inhibitors. FEBS Lett 481: 205-208, 2000

95. Liu A, Du W, Liu JP, Jessell TM, Prendergast GC: RhoB alteration is necessary for apoptotic and antineoplastic responses to farnesyltransferase inhibitors. Mol Cell Biol 20: 6105-6113, 2000

96. Hart MJ, Eva A, Evans T, Aaronson SA, Cerione RA: Catalysis of guanine nucleotide exchange on the CDC42Hs protein by the dbl oncogene product. Nature 354: 311-314, 1991

97. Ron D, Zannini M, Lewis M, Wickner RB, Hunt LT, Graziani G, Tronick SR, Aaronson SA, Eva A: A region of proto-dbl essential for its transforming activity shows sequence similarity to a yeast cell cycle gene, $\mathrm{CDC} 24$, and the human breakpoint cluster gene, bcr. New Biol 3: 372-379, 1991

98. Bi F, Debreceni B, Zhu K, Salani B, Eva A, Zheng Y: Autoinhibition mechanism of proto-Dbl. Mol Cell Biol 21: 1463-1474, 2001

99. Aghazadeh B, Lowry WE, Huang XY, Rosen MK: Structural basis for relief of autoinhibition of the Dbl homology domain of proto-oncogene Vav by tyrosine phosphorylation. Cell 102: 625-633, 2000

100. Hoffman GR, Cerione RA: Signaling to the Rho GTPases: networking with the DH domain. FEBS Lett 513: 85-91, 2002

101. Rebecchi MJ, Scarlata S: Pleckstrin homology domains: a common fold with diverse functions. Annu Rev Biophys Biomol Struct 27: 503-528, 1998

102. Snyder JT, Rossman KL, Baumeister MA, Pruitt WM, Siderovski DP, Der CJ, Lemmon MA, Sondek J: Quantitative analysis of the effect of phosphoinositide interactions on the function of Dbl family proteins. J Biol Chem 276: 45868-45875, 2001

103. Bellanger JM, Astier C, Sardet C, Ohta Y, Stossel TP, Debant A: The Rac-1 and RhoG-specific GEF domain of Trio targets filamin to remodel cytoskeletal actin. Nat Cell Biol 2: $888-892,2000$

104. Taya S, Inagaki N, Sengiku H, Makino H, Iwamatsu A, Urakawa I, Nagao K, Kataoka S, Kaibuchi K: Direct interaction of insulin-like growth factor-1 receptor with leukemiaassociated RhoGEF. J Cell Biol 155: 809-820, 2001

105. Buchsbaum RJ, Connolly BA, Feig LA: Interaction of Rac exchange factors Tiam1 and Ras-GRF1 with a scaffold for the $\mathrm{p} 38$ mitogen-activated protein kinase cascade. Mol Cell Biol 22: 4073-4085, 2002

106. Roof RW, Dukes BD, Chang JH, Parsons SJ: Phosphorylation of the p190 RhoGAP N-terminal domain by c-Src results in a loss of GTP binding activity. FEBS Lett 472: 117-121, 2000

107. Sachdev P, Zeng L, Wang LH: Distinct role of phosphatidylinositol 3-kinase and Rho family GTPases in Vav3induced cell transformation, cell motility, and morphological changes. J Biol Chem 277: 17638-17648, 2002 
108. Bossu P, Vanoni M, Wanke V, Cesaroni MP, Tropea F, Melillo G, Asti C, Porzio S, Ruggiero P, Di CV, Maurizi G, Ciabini A, Alberghina L: A dominant negative RASspecific guanine nucleotide exchange factor reverses neoplastic phenotype in K-ras transformed mouse fibroblasts. Oncogene 19: 2147-2154, 2000

109. Sasaoka T, Langlois WJ, Leitner JW, Draznin B, Olefsky JM: The signaling pathway coupling epidermal growth factor receptors to activation of p21ras. J Biol Chem 269: 32621-32625, 1994

110. Pandey A, Podtelejnikov AV, Blagoev B, Bustelo XR, Mann M, Lodish HF: Analysis of receptor signaling pathways by mass spectrometry: identification of vav-2 as a substrate of the epidermal and platelet-derived growth factor receptors. Proc Natl Acad Sci USA 97: 179-184, 2000

111. Tamas P, Solti Z, Buday L: Membrane-targeting is critical for the phosphorylation of Vav2 by activated EGF receptor. Cell Signal 13: 475-481, 2001

112. Moores SL, Selfors LM, Fredericks J, Breit T, Fujikawa K, Alt FW, Brugge JS, Swat W: Vav family proteins couple to diverse cell surface receptors. Mol Cell Biol 20: 6364-6373, 2000

113. Bustelo XR: Vav proteins, adaptors and cell signaling. Oncogene 20: 6372-6381, 2001

114. Kline JB, Moore DJ, Clevenger CV: Activation and association of the Tec tyrosine kinase with the human prolactin receptor: mapping of a Tec/Vav1-receptor binding site. Mol Endocrinol 15: 832-841, 2001

115. Ridley AJ, Self AJ, Kasmi F, Paterson HF, Hall A, Marshall CJ, Ellis C: rho family GTPase activating proteins p190, bcr and rhoGAP show distinct specificities in vitro and in vivo. EMBO J 12: 5151-5160, 1993

116. Lancaster CA, Taylor-Harris PM, Self AJ, Brill S, van Erp HE, Hall A: Characterization of rhoGAP. A GTPaseactivating protein for rho-related small GTPases. J Biol Chem 269: 1137-1142, 1994

117. Zhang B, Zheng Y: Regulation of RhoA GTP hydrolysis by the GTPase-activating proteins p190, p50RhoGAP, Bcr, and 3BP-1. Biochemistry 37: 5249-5257, 1998

118. Ellis C, Moran M, McCormick F, Pawson T: Phosphorylation of GAP and GAP-associated proteins by transforming and mitogenic tyrosine kinases. Nature 343: 377-381, 1990

119. Burbelo PD, Miyamoto S, Utani A, Brill S, Yamada KM, Hall A, Yamada Y: p190-B, a new member of the Rho GAP family, and Rho are induced to cluster after integrin crosslinking. J Biol Chem 270: 30919-30926, 1995

120. Tikoo A, Czekay S, Viars C, White S, Heath JK, Arden K, Maruta H: p190-A, a human tumor suppressor gene, maps to the chromosomal region $19 \mathrm{q} 13.3$ that is reportedly deleted in some gliomas. Gene 257: 23-31, 2000

121. Settleman J, Narasimhan V, Foster LC, Weinberg RA: Molecular cloning of cDNAs encoding the GAP-associated protein p190: implications for a signaling pathway from ras to the nucleus. Cell 69: 539-549, 1992

122. Tatsis N, Lannigan DA, Macara IG: The function of the p190 Rho GTPase-activating protein is controlled by its N-terminal GTP binding domain. J Biol Chem 273: 34631-34638, 1998

123. Foster R, Hu KQ, Shaywitz DA, Settleman J: p190 RhoGAP, the major RasGAP-associated protein, binds GTP directly. Mol Cell Biol 14: 7173-7181, 1994

124. Hu KQ, Settleman J: Tandem SH2 binding sites mediate the RasGAP-RhoGAP interaction: a conformational mechanism for SH3 domain regulation. EMBO J 16: 473-483, 1997
125. Vincent S, Settleman J: Inhibition of RhoGAP activity is sufficient for the induction of Rho-mediated actin reorganization. Eur J Cell Biol 78: 539-548, 1999

126. Fincham VJ, Chudleigh A, Frame MC: Regulation of p190 Rho-GAP by v-Src is linked to cytoskeletal disruption during transformation. J Cell Sci 112(Pt 6): 947-956, 1999

127. Roof RW, Haskell MD, Dukes BD, Sherman N, Kinter M, Parsons SJ: Phosphotyrosine (p-Tyr)-dependent and -independent mechanisms of p190 RhoGAP-p120 RasGAP interaction: Tyr 1105 of p190, a substrate for c-Src, is the sole p-Tyr mediator of complex formation. Mol Cell Biol 18: 7052-7063, 1998

128. Haskell MD, Nickles AL, Agati JM, Su L, Dukes BD, Parsons SJ: Phosphorylation of p190 on Tyr1105 by cSrc is necessary but not sufficient for EGF-induced actin disassembly in C3H10T1/2 fibroblasts. J Cell Sci 114: 1699-1708, 2001

129. Wang Z, Tung PS, Moran MF: Association of p120 ras GAP with endocytic components and colocalization with epidermal growth factor (EGF) receptor in response to EGF stimulation. Cell Growth Differ 7: 123-133, 1996

130. Kulkarni SV, Gish G, van der GP, Henkemeyer M, Pawson T: Role of p120 Ras-GAP in directed cell movement. J Cell Biol 149: 457-470, 2000

131. Kinch MS, Petch L, Zhong C, Burridge K: E-cadherin engagement stimulates tyrosine phosphorylation. Cell Adhes Commun 4: 425-437, 1997

132. Zrihan-Licht S, Fu Y, Settleman J, Schinkmann K, Shaw L, Keydar I, Avraham S, Avraham H: RAFTK/Pyk2 tyrosine kinase mediates the association of p190 RhoGAP with RasGAP and is involved in breast cancer cell invasion. Oncogene 19: 1318-1328, 2000

133. Chakravarty G, Roy D, Gonzales M, Gay J, Contreras A, Rosen JM: P190-B, a Rho-GTPase-activating protein, is differentially expressed in terminal end buds and breast cancer. Cell Growth Differ 11: 343-354, 2000

134. Trahey M, Wong G, Halenbeck R, Rubinfeld B, Martin GA, Ladner M, Long CM, Crosier WJ, Watt K, Koths K: Molecular cloning of two types of GAP complementary DNA from human placenta. Science 242: 1697-1700, 1988

135. Halenbeck R, Crosier WJ, Clark R, McCormick F, Koths K: Purification, characterization, and western blot analysis of human GTPase-activating protein from native and recombinant sources. J Biol Chem 265: 21922-21928, 1990

136. Zhang Y, Zhang G, Mollat P, Carles C, Riva M, Frobert Y, Malassine A, Rostene W, Thang DC, Beltchev B: Purification, characterization, and cellular localization of the 100-kDa human placental GTPase-activating protein. J Biol Chem 268: 18875-18881, 1993

137. Ye F, Cayre YE, Thang MN: Evidence for a novel RasGAPassociated protein of $105 \mathrm{kDa}$ in both mature trophoblasts and differentiating choriocarcinoma cells. Biochem Biophys Res Commun 263: 523-527, 1999

138. Cheng JC, Frackelton Jr AR, Bearer EL, Kumar PS, Kannan B, Santos-Moore A, Rifai A, Settleman J, Clark JW: Changes in tyrosine-phosphorylated p190 and its association with p120 type I and p100 type II rasGAPs during myelomonocytic differentiation of human leukemic cells. Cell Growth Differ 6: 139-148, 1995

Address for offprints and correspondence: K.L. van Golen, $\mathrm{PhD}$, Department of Internal Medicine, The University of Michigan Comprehensive Cancer Center, 7216A CCGC, 1500 East Medical Center Drive, Ann Arbor, MI 48109-0948, USA; Tel.: +1-734-936-8906; E-mail:kgolen@umich.edu 